\title{
Consensus
}

Volume 32

Issue 1 Cultural Reception of the Gospel

Article 21

5-1-2007

\section{Crossing the divide: Luther, feminism, and the cross}

Oscar Cole-Arnal

Follow this and additional works at: http://scholars.wlu.ca/consensus

\section{Recommended Citation}

Cole-Arnal, Oscar (2007) "Crossing the divide: Luther, feminism, and the cross," Consensus: Vol. 32 : Iss. 1 , Article 21. Available at: http://scholars.wlu.ca/consensus/vol32/iss1/21

This Book Reviews is brought to you for free and open access by Scholars Commons @ Laurier. It has been accepted for inclusion in Consensus by an authorized editor of Scholars Commons@ Laurier. For more information, please contact scholarscommons@wlu.ca. 


\section{Crossing the Divide: Luther, Feminism and the Cross}

Deanna A. Thompson

Minneapolis: Fortress Press, 2004

184 pages, $\$ 21.50$ Softcover

For Lutherans immersed in the theology of the cross while insisting upon radical gender equality under the rubric of the Gospel, Deanna A. Thompson's Crossing the Divide: Luther, Feminism and the Cross, is a must. Having pursued my spiritual journey as a "justification by grace alone through faith alone" Lutheran for the last fifty years, I find her book that breath of fresh air for which I have searched for at least three of those five decades. I deem Dr. Thompson's volume to be profoundly honest, profoundly engaging, profoundly challenging and profoundly faithful to both the Biblical and core traditions of our faith. My explanations follow.

Profoundly honest: sadly I find most books that deal with Luther's theology of the cross to be disturbing by their refusal to deal with Luther's failures beyond the wearying dollop of "well, he was a man of his time." Not so Thompson! She exposes boldly his rabid anti-Semitism, his blind sexism, and his class indifference to the peasants' perception of the Gospel and without the standard Lutheran defensiveness. Further, she acknowledges her own class and ethnic/racial privilege, not as a "throw away" sidebar but as part of the essential limitations under which she operates. In these clear expressions of honesty (the like of which I see so rarely in Lutheran academics) I perceive the fresh air of the Spirit.

Profoundly engaging and profoundly challenging: Crossing the Divide is an easy book to read, not because it is simplistic but rather because it is so well-written, clear, inspiring in its style and demanding in its challenge to think and live under the cross in radical Gospel equality.

Profoundly faithful to the Bible and Luther's Core Theology: To be true to both the Bible and Luther's perceptions involves a deep wrestling that moves beyond the assumptions of Lutheran theology for the last almost five hundred years. In my seminary days we found it rather easy to interlink Luther's cross and grace theology with the intoxicating brand of existentialism expressed so profoundly by Rudolf Bultmann and his school: gender played no part, subtle and not-so-subtle anti-Semitism remained, and the individualism of 
"Bultmannians" and Luther was a marriage made in heaven. Thompson explodes all that. Willy-nilly she returns to the collective and social impact of New Testament "grace" by moving Luther beyond the narrow framework of the inwardly spiritual and outwardly status quo. She demands of Luther the kind of Biblical incarnation of radical grace that screams "in Christ, there is neither Jew nor Greek, slave nor free, male nor female."

I am convinced with all my heart that this book emerges as so important that it should not be consigned to a "feminist" optional text in systematic theology, as a recommended read after the required reading of the fine work The Cross in Context, by Douglas John Hall, or similar works by authors like Gerhard Forde. It is time to relegate them to optional readings and make Deanna Thompson's Crossing the Divide the seminal text in Lutheran courses on systematic theology. This book shines like a beacon and finally helps us articulate a "justification by grace alone through faith alone" theology that has flesh and blood.

Oscar Cole-Arnal

Waterloo Lutheran Seminary

Waterloo, Ontario

\section{Stewards, Prophets, Keepers of the Word: Leadership in} the Early Church

Ritva H. Williams

Peabody, Mass.: Hendrickson, 2006

xii +228 pages, $\$ 30.00$ Softcover

My over-all assessment heralds this first effort as a most significant contribution to New Testament scholarship. And yet there are some weaknesses in this work, which I attribute to the challenge and difficulty of turning a doctoral thesis into a book. At times the content was repetitive, and the prose not sufficiently crisp. Sometimes it seemed as if Williams was just listing themes, point by point, without a compelling sense of integration. At times this gives her work a static character, when the reality of these early communities was more dynamic than the structure of the book might imply. At the same time, 